\title{
Hypovitaminosis D and Its Associated Factors in North Algerian Postmenopausal Women: Results of a Cross-Sectional Study
}

\author{
S. Oussedik-Lehtihet, ${ }^{1}$ C. Haouichat, ${ }^{1}$ N. Hammoumraoui, ${ }^{1}$ E. Ducros, ${ }^{2}$ \\ C. Gouhier-Kodas, ${ }^{2}$ S. Lancrenon, ${ }^{3}$ and H. Djoudi ${ }^{1}$ \\ ${ }^{1}$ Centre Hospitalier Universitaire de Douera, Rue des Frères Halim, Douera 16000, Alger, Algeria \\ ${ }^{2}$ Laboratoire Innotech International, 22 Avenue Aristide Briand, 94110 Arcueil, France \\ ${ }^{3}$ Sylia-Stat, 10 Boulevard du Maréchal Joffre, 92340 Bourg-la-Reine, France \\ Correspondence should be addressed to S. Oussedik-Lehtihet; lehtihet_samira@yahoo.fr
}

Received 16 June 2017; Revised 6 October 2017; Accepted 29 October 2017; Published 17 December 2017

Academic Editor: Pedro Moreira

Copyright (c) 2017 S. Oussedik-Lehtihet et al. This is an open access article distributed under the Creative Commons Attribution License, which permits unrestricted use, distribution, and reproduction in any medium, provided the original work is properly cited.

Purpose. As the vitamin D status of Algerian postmenopausal women was poorly described, this cross-sectional study investigated the prevalence of low vitamin D status in a sample population. Secondarily, predictive factors of this hypovitaminosis D were explored. Methods. All the 336 selected women $\geq 45$ years from Douera were interviewed to get anthropometric and lifestyle data, reproductive and medical history, medications, and calcium/vitamin D intakes. A blood sample was collected to measure 25 -hydroxyvitamin D (25(OH)D) concentrations. Results. Approximately $86 \%$ of subjects had low vitamin D status $(<20 \mathrm{ng} / \mathrm{mL})$. Mean 25(OH)D level was $14.4 \pm 5.3 \mathrm{ng} / \mathrm{mL}$ with a clear seasonal dynamic and a significant negative correlation with PTH levels $(r=-0.15, p=0.006)$. A multiple regression analysis using the $25(\mathrm{OH}) \mathrm{D}$ cutoff value of $17 \mathrm{ng} / \mathrm{mL}$ instead of the generally admitted level of $20 \mathrm{ng} / \mathrm{mL}$ was performed to increase statistical power. Other seasons than summer (OR 4.159 and $95 \%$ CI $2.456-7.043)$, obesity ( $\geq 30 \mathrm{~kg} / \mathrm{m}^{2}$, OR $1.826,95 \%$ CI 1.081-3.083), and veiling (OR $3.526,95 \%$ CI $1.090-11.400$ ) were significantly associated with $25(\mathrm{OH}) \mathrm{D}$ concentrations $<17 \mathrm{ng} / \mathrm{mL}$. Conclusions. In North Algeria, the abundant sunlight appears insufficient to fully offset hypovitaminosis D risk factors in postmenopausal women, especially obesity and veiling. It suggests the major need to increase vitamin D supplementation in this subpopulation.

\section{Introduction}

Vitamin D inadequacy is highly prevalent worldwide [1] and has well-known direct and deleterious consequences on bone health. This mainly occurs via secondary hyperparathyroidism, leading to excessive bone remodelling and ultimately to bone weakening, which in turn increases fragility fracture risk. Vitamin D deficiency leads to rickets in children and osteomalacia in adults, and long-term insufficiency contributes to osteoporosis [2, 3]. Serum circulating 25-hydroxyvitamin D $(25(\mathrm{OH}) \mathrm{D})$ level is considered as the best indicator of the body vitamin $\mathrm{D}$ status, and although still debated, most experts defined vitamin D deficiency as $25(\mathrm{OH}) \mathrm{D}$ levels lower than $20 \mathrm{ng} / \mathrm{mL}[4,5]$.

Despite the fact that all age groups may be affected, it became evident that vitamin $\mathrm{D}$ inadequacy is particularly common among older adults, which is of substantial concern in the context of the significant increase in ageing populations and life expectancies worldwide. Lack of exposure to sunlight, which is the primary source of vitamin $\mathrm{D}$, poor nutrition, and a decrease in the capacity to produce vitamin $\mathrm{D}_{3}$ in the skin are the main hypothesized causative factors of vitamin D inadequacy in this subpopulation [6]. Hence, not surprisingly, postmenopausal women from different countries were reported to be particularly vulnerable to vitamin D deficiency, which leads numerous international health authorities and medical societies to produce recommendations for the management of postmenopausal osteoporosis by maintaining adequate vitamin $\mathrm{D}$ levels by supplementation.

However, data obtained from various populations of community-living postmenopausal women with or without osteoporosis highlight a wide disparity of prevalence rates of $25(\mathrm{OH}) \mathrm{D}$ concentration $\leq 20 \mathrm{ng} / \mathrm{mL}$ depending on the considered geographical areas $[7,8]$. For instance, in a European 
study involving more than 8500 postmenopausal women, the prevalence of $25(\mathrm{OH}) \mathrm{D}$ deficiency reached $32.1 \%$ when considering the cutoff value of $20 \mathrm{ng} / \mathrm{mL}$ [9], while in Indian, Chinese, and US populations of postmenopausal women, the estimated prevalence rates were $53.3 \%, 72.1 \%$, and $53 \%$, respectively [10-12].

Data related to the vitamin D status of postmenopausal women in North Africa are scanty or lacking, and to our knowledge, such information has not been documented in Algeria. Located in the Mediterranean basin, Algeria is characterized by a climate that is mostly sunny around the year. Consequently, since vitamin D status is most strongly influenced by skin synthesis resulting from exposure to UVB (sunlight), a proper amount of vitamin D is theoretically to be expected in Algerian postmenopausal women. Nevertheless, there is accumulating evidence of the frequent occurrence of subclinical vitamin $\mathrm{D}$ deficiency in populations living in sunny countries [13-17]. Moreover, vitamin D insufficiency was recently found to be frequent in healthy Algerian children [18].

Hence, although extrapolating the prevalence data from countries of similar climates and latitudes should be cautious because of other influencing factors like diet on vitamin D status, we hypothesized that Algerian postmenopausal women may not be an exception and that vitamin D inadequacy may be relatively prevalent in this age group. To provide an estimation of the magnitude of the problem in our country, a cross-sectional study was carried out to determine the vitamin $\mathrm{D}$ status among a healthy postmenopausal women population recruited in Douera, a city located in the extreme northern part of Algeria. The secondary objective was to identify the determinants of hypovitaminosis $\mathrm{D}$ in order to identify the most vulnerable patients on whom public health actions should be primary focused.

\section{Methods}

2.1. Study Design and Population. This cross-sectional prospective study was conducted between April 2008 and November 2009 in Douera, a city of approximately 57,000 inhabitants located in the district of Algiers (Algeria) at a latitude of $36^{\circ} 40^{\prime}$ North and whose demographic characteristics, notably in terms of age and gender distribution, are representative of those of the whole Algerian population (Office National des Statistiques, Algeria, http://www.ons.dz). Participants were recruited by medical students according to a traditional and recognized door-to-door sampling method. After a short interview using a structured questionnaire in their homes, the eligible female patients were invited to participate in the study and to attend the Specialized Hospital Establishment (EHS) of Douera. All volunteer participants were provided with full information about the study's purpose, and they gave informed consent to participate in the study. The study was approved by the ethics committee of the hospital.

Interviewed women had to meet the following inclusion criteria: age 45 years or older, living in Douera, and being postmenopausal. The main noninclusion criteria were any musculoskeletal, thyroid, hepatic, or renal diseases, granulomatous diseases, sequels of extensive burn injuries, or intake of any medication that may impact vitamin $\mathrm{D}$ status or bone metabolism (e.g., glucocorticoids and anticonvulsants), including calcium and/or vitamin D supplementation and multivitamin supplementation during the three preceding months. Additionally, patients who had been treated with osteoporotic medications (e.g., hormonal replacement therapy, selective estrogen receptor modulators, and bisphosphonates) within the previous 6 months were not recruited into the study.

2.2. Clinical and Sociodemographic Characteristics. After the participants signed the informed consent, they underwent a clinical examination. The clinical data collected included age, height, and weight. Body mass index (BMI) was then calculated using these anthropometric data as body weight in kilograms divided by height in meter squared. Medical (e.g., existence of chronic illness) and obstetrical (parity) histories, age at menopause, current medications, and socioeconomic status (education level and profession) were also obtained by an experienced investigator. Participants were also asked to describe their previous fractures, if any (number and site).

On the same day, bone mineral density (BMD) at L1-L4 lumbar spine and total hip, expressed in grams per centimeter squared, was measured in all participating women by dual energy X-ray absorptiometry (DXA-QDR-2000/W, Hologic Inc.). Daily quality control was performed by phantom measurements (DPA/QDR-1 anthropomorphic spine phantom). At the time of the study, phantom measurements showed stable results. The phantom precision expressed as the coefficient of variation percentage was $3 \%$. T-scores of the lumbar spine and total hip were calculated using the reference curve obtained with the French OFELY cohort [19], preferred to the US NHANES reference curve in the absence of an Algerian one, and both were previously shown to give comparable results [20]. The World Health Organization classification system was applied, defining osteoporosis as T-score $\leq-2.5$ and osteopenia as T-score between -2.5 and -1 [21].

2.3. Questionnaires. A series of questionnaires were used for data collection. The skin phototype was determined according to the Fitzpatrick classification from I (pale white skin) to VI (dark brown or black skin). Daily sun exposure (average duration and sun-exposed body areas) and dressing habits were evaluated by direct questioning. Similarly, the mean weekly vitamin $\mathrm{D}$ intake from food was assessed using a sixquestion tool $[22,23]$. The daily calcium intake was calculated using the validated self-questionnaire of Fardellone and coworkers [24], adapted to the Algerian eating habits.

2.4. Laboratory Tests. A venous blood sample was collected on the same day of bone density measurement for the determination of 25-hydroxyvitamin D (25(OH)D) and parathyroid hormone (PTH) serum concentrations by electrochemiluminescence immunoassay using the Roche Elecsys 2010 COBAS system. This method can measure the concentration of $25(\mathrm{OH}) \mathrm{D}$ in the range of $10-250 \mathrm{nmol} / \mathrm{L}$, and $\mathrm{PTH}$ in the range of 
$1.2-5000 \mathrm{pg} / \mathrm{mL}$. All laboratory tests were performed at the Specialized Hospital Establishment (EHS) of Douera.

2.5. Statistical Analysis. Analyses were performed with SAS software (version 9.4, SAS Institute Inc., Cary, NC), and statistical significance was defined as a value of $p<0.05$.

To compare two groups, we used the chi-square test for categorical variables expressed as frequencies, the $t$-test for continuous variables expressed as mean \pm standard deviation (SD), and the nonparametric Mann-Whitney test when the assumption of normality was questionable. To compare more than two groups, we used the chi-square test for categorical variables, a one-way analysis of variance for continuous variables, and the nonparametric Kruskal-Wallis test when the assumption of normality was questionable. Pearson's correlation was used to study the relationship between quantitative variables.

A multiple logistic regression analysis was used to identify the factors best explaining a lower level of 25(OH)D. A stepwise procedure was used to select variables. Stepping was stopped when there were no further candidate variables that would enter the model at the 5\% significance level.

\section{Results}

A total of 400 women were contacted, interviewed, and screened. Less than $10 \%$ of the screened participants did not attend the EHS of Douera to undergo the clinical examination. Among the participants who were attending the hospital, some presented with noninclusion criteria and were excluded (currently with thyroid disease, treatment with osteoporotic medications within the previous 6 months, or treatment with calcium and/or vitamin D supplements during the three preceding months).

3.1. Sociodemographic and Clinical Characteristics of the Population. The study involved 336 women, mainly without any education level (57.7\%), residing in the urban areas of Douera (74.1\%), and aged between 45 and 87 years (Table 1 ). The recruitment of participants was well balanced over the seasons. The average parity was 6.5 children per woman, and the mean age at menopause was 47.4 years. More than half of the study participants had skin phototypes I-III (50.6\%), while $49.5 \%$ had skin phototypes IV-V. Almost all women (96.1\%) wore a veil covering their hair, arms, and legs. The mean BMI was $28.51 \pm 5.32 \mathrm{~kg} / \mathrm{m}^{2}$. One hundred and forty subjects $(42.6 \%)$ were obese $\left(\mathrm{BMI} \geq 30 \mathrm{~kg} / \mathrm{m}^{2}\right)$, while 117 (35.6\%) were overweight $\left(25 \mathrm{~kg} / \mathrm{m}^{2} \leq \mathrm{BMI}<30 \mathrm{~kg} / \mathrm{m}^{2}\right)$.

The participants did not take any calcium nor vitamin D supplements within the three months prior to the study. The daily dietary calcium intake was estimated to be less than $500 \mathrm{mg} /$ day in $58.3 \%$ of the participating women, which is much lower than the recommended daily allowance ranging from 1000 to $1200 \mathrm{mg}$ /day in this population [4]. On the basis of a questionnaire, the mean daily vitamin $\mathrm{D}$ intake from dietary sources was estimated to be $1.4 \pm 1.1 \mu \mathrm{g} /$ day $(56 \pm 44 \mathrm{IU} /$ day $)$. Self-report on sun exposure of subjects was not analyzed because most of the
TABLE 1: Sociodemographic, biochemical, and clinical characteristics of the study population $(n=336)$.

\begin{tabular}{|c|c|c|c|}
\hline & & $\begin{array}{c}\text { Mean } \pm \text { SD } \\
\text { or percentage }\end{array}$ & Min-max \\
\hline \multicolumn{4}{|c|}{ Sociodemographic parameters } \\
\hline Age (years) & - & $60.1 \pm 8.5$ & $45.0-87.0$ \\
\hline $\begin{array}{l}\text { Age at menopause } \\
\text { (years) }\end{array}$ & - & $47.4 \pm 4.8$ & $26.0-57.0$ \\
\hline $\begin{array}{l}\text { Seasons of } \\
\text { recruitment }\end{array}$ & $\begin{array}{l}\text { Winter } \\
\text { Spring } \\
\text { Summer } \\
\text { Autumn }\end{array}$ & $\begin{array}{l}23.5 \% \\
26.8 \% \\
25.0 \% \\
24.7 \%\end{array}$ & $\begin{array}{l}- \\
- \\
-\end{array}$ \\
\hline $\begin{array}{l}\text { Number of } \\
\text { children }\end{array}$ & - & $6.5 \pm 3.5$ & $0.0-16.0$ \\
\hline \multirow{2}{*}{$\begin{array}{l}\text { Education } \\
\text { level/schooling (\%) }\end{array}$} & $\begin{array}{c}\text { None } \\
\text { Primary } \\
\text { education }\end{array}$ & $57.7 \%$ & - \\
\hline & $\begin{array}{c}\text { Average level } \\
\text { University } \\
\text { level }\end{array}$ & $15.5 \%$ & - \\
\hline Skin phototype & $\begin{array}{c}\text { I-III } \\
\text { IV } \\
\text { V }\end{array}$ & $\begin{array}{c}50.6 \% \\
43.8 \% \\
5.7 \%\end{array}$ & $\begin{array}{l}- \\
- \\
-\end{array}$ \\
\hline Veiling & $\begin{array}{l}\text { Yes } \\
\text { No }\end{array}$ & $\begin{array}{c}96.1 \% \\
3.9 \%\end{array}$ & $\begin{array}{l}- \\
-\end{array}$ \\
\hline Rural or urban area & $\begin{array}{l}\text { Urban } \\
\text { Rural }\end{array}$ & $\begin{array}{l}74.1 \% \\
25.9 \%\end{array}$ & $\begin{array}{l}- \\
-\end{array}$ \\
\hline $\begin{array}{l}\text { Daily calcium } \\
\text { intake }\end{array}$ & $\begin{array}{c}-\bar{c} \\
<500 \mathrm{mg} \\
\geq 500-<700 \mathrm{mg} \\
\geq 700-<800 \mathrm{mg} \\
\geq 800 \mathrm{mg}\end{array}$ & $\begin{array}{c}491.0 \pm 181.3 \\
58.3 \% \\
30.1 \% \\
5.4 \% \\
6.3 \%\end{array}$ & $\begin{array}{c}149.6-1334.9 \\
- \\
- \\
- \\
-\end{array}$ \\
\hline $\begin{array}{l}\text { Daily vitamin D } \\
\text { intake (IU) }\end{array}$ & - & $56 \pm 44$ & $0-220$ \\
\hline \multicolumn{4}{|l|}{ Clinical parameters } \\
\hline BMI $\left(\mathrm{kg} / \mathrm{m}^{2}\right)$ & - & $28.5 \pm 5.3$ & $15.0-50.0$ \\
\hline $\mathrm{T}$-score $\leq-2.5$ & $\begin{array}{c}\text { Hip } \\
\text { Lumbar spine }\end{array}$ & $\begin{array}{l}12.8 \% \\
32.2 \%\end{array}$ & - \\
\hline Osteoporosis* & - & $32.8 \%$ & - \\
\hline \multicolumn{3}{|c|}{ Biochemical parameters } & - \\
\hline $25(\mathrm{OH}) \mathrm{D}(\mathrm{ng} / \mathrm{mL})$ & - & $14.4 \pm 5.3$ & $4.0-35.9$ \\
\hline PTH $(\mathrm{pg} / \mathrm{mL})$ & - & $64.2 \pm 25.1$ & $14.0-179.6$ \\
\hline
\end{tabular}

${ }^{*} \mathrm{~T}$-score of the lumbar spine and/or lower hip $\leq-2.5$; IU: international units; SD: standard deviation.

women did not report or report only very limited exposure to the sun, even in their garden or courtyards, for example. The diagnosis of osteoporosis was confirmed by a T-score of hip and/or lumbar spine $\leq-2.5$ in $32.8 \%$ of the participants. Based on self-report history, the number of subjects with a history of at least one fracture was 54 (16.1\%). The most frequent site of the fracture was the wrist $(n=15)$. Other fractures were located in the lower $(n=22)$ or upper $(n=9)$ parts or were thoracic fractures $(n=3)$. Three participants could not remember the exact localization of their previous fracture. 


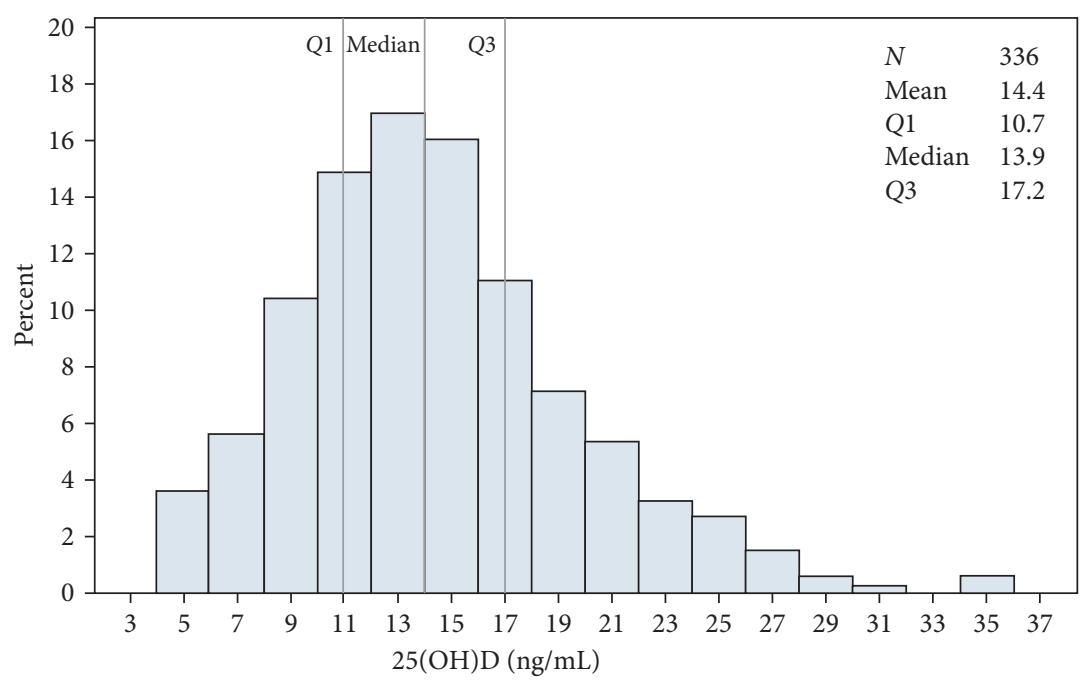

FIGURE 1: Distribution of the 25-hydroxyvitamin D $(25(\mathrm{OH}) \mathrm{D})$ concentrations across the entire study population $(n=336)$.

3.2. Serum 25(OH)D and Prevalence of Hypovitaminosis $D$. The mean serum concentration of $25(\mathrm{OH}) \mathrm{D}$ for all 336 subjects was $14.4 \pm 5.3 \mathrm{ng} / \mathrm{mL}$. The prevalence of circulating $25(\mathrm{OH}) \mathrm{D}$ levels less than $20 \mathrm{ng} / \mathrm{mL}$ was $85.7 \%$. The 25 th and 75 th percentiles of the distribution of $25(\mathrm{OH}) \mathrm{D}$ concentrations were 10.7 and $17.2 \mathrm{ng} / \mathrm{mL}$, respectively. The distribution of subjects across ranges of $25(\mathrm{OH}) \mathrm{D}$ concentrations is shown in Figure 1. A seasonal dynamic in $25(\mathrm{OH}) \mathrm{D}$ levels was described with a peak in the summer months versus the other three pooled seasons $(17.2 \pm 6.2$ versus $13.4 \pm$ $4.7 \mathrm{ng} / \mathrm{mL}, p<0.0001$, Mann-Whitney test). It should be noted that the different seasons were determined according to local criteria: winter covers December, January, and February; spring covers March, April, and May; summer covers June, July, and August; and autumn covers September, October, and November.

A significant negative correlation was observed between PTH and 25(OH)D levels (Pearson's correlation coefficient $=-0.15186, p=0.006)$. The mean PTH concentration was $64.2 \pm 25.1 \mathrm{pg} / \mathrm{mL}$. Changes in serum PTH concentrations were observed across the months with significantly higher levels measured during the winter months versus the other seasons $(77.8 \mathrm{pg} / \mathrm{mL}$ versus $60.5 \mathrm{pg} / \mathrm{mL}$, $p<0.0001$, Mann-Whitney test). No other significant linear correlation was found between $25(\mathrm{OH}) \mathrm{D}$, and the other tested factors, in particular, T-score (hip and spine), BMD (hip and spine), or dietary calcium intake.

3.3. Factors Associated with Low 25(OH)D Concentrations. Unidimensional analyses were performed to determine which subject characteristics were associated with hypovitaminosis $\mathrm{D}$ and to identify the potential risk factors. As the number of subjects with $25(\mathrm{OH}) \mathrm{D}$ concentration $>20 \mathrm{ng} / \mathrm{mL}$ was insufficient to ensure adequate statistical power, the cutoff value of $17 \mathrm{ng} / \mathrm{mL}$ was considered for these analyses. This value corresponded to the 75th percentile for serum $25(\mathrm{OH}) \mathrm{D}$ and allowed a less unbalanced distribution of subjects between groups. A low vitamin D status, defined as $25(\mathrm{OH})$
D concentrations lower than $17 \mathrm{ng} / \mathrm{mL}$, was significantly associated with obesity $\left(\mathrm{BMI}>30 \mathrm{~kg} / \mathrm{m}^{2}\right)(p=0.05)$ (Table 2$)$. There was also a tendency toward an association with veiling $(p<0.1)$.

A stepwise multiple logistic regression model was developed to further explore the independent variables with a statistical or a near-statistical association with low vitamin D status, defined as $25(\mathrm{OH}) \mathrm{D}$ levels $<17 \mathrm{ng} / \mathrm{mL}$, in the univariate analysis. Hypovitaminosis $\mathrm{D}$ was found to be significantly associated with obesity (BMI in two categories: $<30 \mathrm{~kg} / \mathrm{m}^{2}$ versus $\geq 30 \mathrm{~kg} / \mathrm{m}^{2} ; \mathrm{OR}=1.826 ; 95 \%$ CI 1.081 , 3.083; $p=0.02$ ), veiling (yes versus no; $\mathrm{OR}=3.526 ; 95 \% \mathrm{CI}$ $1.090,11.400 ; p=0.0353$ ), and the season (summer versus other pooled seasons; $\mathrm{OR}=4.159 ; 95 \%$ CI 2.456, 7.043; $p<0.0001)$.

\section{Discussion}

To our knowledge, this is the first report on the vitamin D status of a group of postmenopausal women living in a sunny area of Northern Algeria. Contrary to what would be expected in an area with such abundant sunshine, results show that the prevalence of vitamin D inadequacy is very high. Indeed, more than $85 \%$ of subjects have $25(\mathrm{OH}) \mathrm{D}$ levels lower than $20 \mathrm{ng} / \mathrm{mL}$, and about $20 \%$ of subjects exhibit severe vitamin D deficiency $(<10 \mathrm{ng} / \mathrm{mL})$. These results are in agreement with the few previous studies that report very high prevalence of hypovitaminosis D in comparable populations of North African sunny regions, at roughly the same latitudes (about $30^{\circ} \mathrm{N}$ ) [25-27]. Hence, in a cohort of 429 postmenopausal women recruited in North Morocco, the mean 25(OH)D level was $14.5 \pm 12.4 \mathrm{ng} / \mathrm{mL}$ and $78.1 \%$ had levels $<20 \mathrm{ng} / \mathrm{mL}$ [26]. Consistently, in a Tunisian population consisting of 389 subjects, including $61 \%$ of females, largely housewives, Meddeb et al. found that $59.5 \%$ of the 50-59-year age group had an average $25(\mathrm{OH}) \mathrm{D}$ level $<15 \mathrm{ng} / \mathrm{mL}$ [27].

Two other major findings are compatible with results generally reported in populations with hypovitaminosis D and further support the validity of our sample set and analysis. 
TABLE 2: Results of the univariate and multivariate logistic regression models for the association of subject characteristics with vitamin $\mathrm{D}$ hypovitaminosis with the cutoff value of $17 \mathrm{ng} / \mathrm{mL}^{*}$.

\begin{tabular}{lccc}
\hline Characteristic & $p$ value* & Modalities for OR calculation & OR (95\% CI) \\
\hline Univariate logistic regression & & & $0.99(0.96-1.02)$ \\
Age & 0.41 & Continuous & $0.99(0.97-1.02)$ \\
Duration of menopause & 0.46 & Continuous & $1.01(0.94-1.09)$ \\
Parity & 0.75 & Continuous & $0.61(0.36-1.01)$ \\
BMI & 0.05 & $<30 \mathrm{~kg} / \mathrm{m}^{2}$ versus $\geq 30 \mathrm{~kg} / \mathrm{m}^{2}$ & $1.31(0.76-2.26)$ \\
Habitat/housing & 0.32 & Urban versus rural & $0.82(0.50-1.33)$ \\
Education level & 0.81 & Education versus no education & $1.13(0.69-1.84)$ \\
Skin phototype & 0.82 & Dark versus light & $2.56(0.84-7.84)$ \\
Veiling & 0.09 & Yes or no & $0.99(0.83-1.18)$ \\
T-score spine & 0.95 & Continuous & $0.98(0.58-1.65)$ \\
DMO spine & 0.93 & Abnormal versus normal & $1.12(0.93-1.36)$ \\
T-score hip & 0.19 & Continuous & $0.80(0.49-1.31)$ \\
DMO hip & 0.67 & Abnormal versus normal & \\
Multivariate logistic regression & & & $1.826(1.081-3.083)$ \\
BMI & 0.02 & $<30 \mathrm{~kg} / \mathrm{m}^{2}$ versus $\geq 30 \mathrm{~kg} / \mathrm{m}^{2}$ & $3.526(1.090-11.400)$ \\
Veiling & 0.0353 & Yes or no & $4.159(2.456-7.043)$ \\
Season & $<0.0001$ & Summer versus other pooled seasons &
\end{tabular}

${ }^{*} p$ value was calculated for each variable according to the Mann-Whitney test or chi-square test.

As universally observed, a significant seasonal variation of serum $25(\mathrm{OH}) \mathrm{D}$ levels is evident $(p<0.0001)$. This finding is generally explained by the fluctuations of sunshine duration, exposure, and intensity over seasons. Interestingly, there is one major peak throughout the year, globally covering the summer months and roughly corresponding to the maximum insolation period. A comparable profile of seasonal variation of $25(\mathrm{OH}) \mathrm{D}$ has recently been observed in a large Mediterranean cohort exposed to a similar climate as that existing in North Algeria [28].

Furthermore, the well-documented inverse relationship between 25(OH)D and PTH is observed. Low levels of $25(\mathrm{OH}) \mathrm{D}$ cause secondary hyperparathyroidism, which preserves normocalcemia at the expense of bone health. The $25(\mathrm{OH}) \mathrm{D}$ concentration below which high levels of PTH ensue has not been established in this study.

In view of the high prevalence of hypovitaminosis $\mathrm{D}$ $(25(\mathrm{OH}) \mathrm{D}$ levels $<20 \mathrm{ng} / \mathrm{mL})$ in the study population, groups with and without a low vitamin $\mathrm{D}$ status are unexpectedly highly unbalanced in size. To gain statistical power and to better identify the factors associated with a low vitamin D status, a univariate analysis was performed using the 75 th percentile as the cutoff value, that is $17 \mathrm{ng} / \mathrm{mL}$. With this cutoff level, no correlation is found between PTH and $25(\mathrm{OH}) \mathrm{D}$ levels. This is consistent with previous data showing that an increase in PTH is detected with $25(\mathrm{OH}) \mathrm{D}$ concentrations equal to or below $15 \mathrm{ng} / \mathrm{mL}$ [29-31] or between 10 and $20 \mathrm{ng} / \mathrm{mL}$ [2].

No significant independent association has been detected between 25(OH)D levels and BMD at any measured site. This is in agreement with some, but not all studies. Rassouli et al. found that serum $25(\mathrm{OH}) \mathrm{D}$ was weakly correlated with the spine but not with the hip BMD in early postmenopausal women with vitamin D deficiency [32]. In the Multiple Outcomes of Raloxifene Evaluation study, a 25(OH)D level below $10 \mathrm{ng} / \mathrm{mL}$ was associated with a $4 \%$ lower trochanteric BMD, although the lumbar spine or the femoral neck BMD did not differ [33]. More recently, no significant difference in BMD or radius BMD loss was demonstrated among women with $25(\mathrm{OH}) \mathrm{D}$ levels below or above 30,20 , or $12 \mathrm{ng} / \mathrm{mL}$ [34]. These discordances in the skeletal site BMD correlation with $25(\mathrm{OH}) \mathrm{D}$ are likely to be linked to differences in sample sizes, selection criteria, country of origin, and perhaps dietary calcium and vitamin intakes among the studied populations. Nevertheless, Bischoff-Ferrari and coworkers reported a correlation, although low and variable among skeletal sites, between these two parameters [35]. This may also support the concept of multifactorial effects of vitamin D on BMD.

After a multilinear regression analysis, being in any other seasons than summer, being obese, and veiling have been found to be independently associated with a vitamin D status lower than $17 \mathrm{ng} / \mathrm{mL}$. The percentage of unveiled women in our sample is too small (3.9\%) to establish a strong and definite association with the vitamin D status. However, the significant influence of the clothing style is not surprising and has already been suggested, notably in Turkey, Middle East countries, and Tunisia [13, 27, 36, 37]. In a study conducted in 251 postmenopausal osteoporotic Lebanese women, $25(\mathrm{OH}) \mathrm{D}$ levels were significantly lower in women with a dress code covering their arms compared with those who did not follow any special dress code (15.1 \pm $6.6 \mathrm{ng} / \mathrm{mL}$ versus $22.5 \pm 10.6 \mathrm{ng} / \mathrm{mL}, p<0.001$ ) [36]. Dress code was identified as an independent predictor of $25(\mathrm{OH}) \mathrm{D}$ inadequacy $(p<0.001)$. A similar difference according to the clothing style was observed in 2013 Jordanian women of reproductive age [37]. Prevalence of deficiency was 1.60 times higher for women covered with a scarf/hijab (95\% CI: 
$1.06-2.40, p=0.024)$ compared with unveiled women. These consistent observations confirm the importance of sun exposure in the synthesis of vitamin $\mathrm{D}$.

In this study, obesity $\left(\mathrm{BMI}>30 \mathrm{~kg} / \mathrm{m}^{2}\right)$ has also been found to be a major predictor of the vitamin $\mathrm{D}$ status of postmenopausal women. A large amount of evidence resulting from observational studies supports a significant link between obesity and lower serum levels of $25(\mathrm{OH}) \mathrm{D}$ regardless of the age [38-40]. Different mechanisms have been proposed to explain this relationship, such as the decreased sun exposure because of decreased mobility and issues of social acceptance or the negative feedback from elevated $1,25(\mathrm{OH})_{2} \mathrm{D}$ and PTH levels on hepatic synthesis of $25(\mathrm{OH}) \mathrm{D}[39,41]$. However, the sequestration and the volumetric dilution theories are probably the most supported within the literature [39]. Wortsman et al. were the first to provide strong evidence that the fat-soluble vitamin $\mathrm{D}$ may become trapped within the adipose tissue [42]. Compared with control lean subjects, obese subjects had a significantly attenuated increase in $25(\mathrm{OH}) \mathrm{D}$ concentration after a whole-body exposure to UVB irradiation, despite a greater body surface area. More recently, convincing data suggest that volumetric dilution may simply explain the low vitamin D status in obesity. In a cohort of 686 otherwise healthy individuals (BMI range: 16.5 to $61.2 \mathrm{~kg} / \mathrm{m}^{2}$ ), an inverse relationship between serum $25(\mathrm{OH}) \mathrm{D}$ and body weight was confirmed but, once adjusted for body size, difference in $25(\mathrm{OH}) \mathrm{D}$ levels between nonobese and obese individuals was removed [43]. Consistently, interventional studies with vitamin D supplements have shown that obese patients need higher vitamin $\mathrm{D}$ dosages than lean individuals to achieve the same $25(\mathrm{OH}) \mathrm{D}$ concentrations $[44,45]$. Hence, the recommendation for obese subjects is an intake of two or three times more vitamin $\mathrm{D}$ than their age group reference [5]. Nevertheless, whether vitamin D deficiency leads to obesity or obesity is responsible for low $25(\mathrm{OH}) \mathrm{D}$ concentrations is still a matter of debate [46-49].

The main limitations of our study lie in its crosssectional design, in the limited geographical area of the recruitment, and in the recruitment process of the participants, mostly housewives with a low education level. However, although caution should be exercised while generalizing our results, the educational and occupational status of the women from our sample does not substantially deviate from that of the Algerian postmenopausal population. Furthermore, the climatic conditions of Douera (seasonality and UVB radiation) correspond to those found near the North coast of the country where approximately $90 \%$ of the Algerian population is living. Another study limitation is the measurement of the $25(\mathrm{OH}) \mathrm{D}$ level performed (i) at a single time point, not the same for all subjects which may have created a confounding seasonal effect, and (ii) using a $25(\mathrm{OH}) \mathrm{D}$ electrochemiluminescence assay that is now known to underestimate $25(\mathrm{OH}) \mathrm{D}$ levels, especially at low levels [26]. Finally, the accuracy of self-reported data concerning lifestyle practices may have been subject to report bias; as with such types of studies, we acknowledge that there may be unrecognized confounding. However, such a high prevalence of hypovitaminosis $\mathrm{D}$ determined using other $25(\mathrm{OH}) \mathrm{D}$ dosage methods has also been reported in neighboring countries or countries located at te same latitude. Furthermore, the predictive factors of low vitamin D status we identified by analysing our data according to a robust statistical methodology have all been already identified as such in other populations.

In conclusion, the most important finding of our study is the critically high prevalence of hypovitaminosis D observed in postmenopausal otherwise healthy North Algerian women, reaching more than $85 \%$. Although derived from a subpopulation of small sample size, these unexpected results in an abundant sunshine region such as North Algeria are of major concern considering the accumulating evidence that vitamin $\mathrm{D}$ deficiency may be linked to a multitude of health risks such as osteoporosis, diabetes, and cardiovascular diseases [50]. Nonsummer season, obesity, and veiling emerged as reliable predictors of hypovitaminosis $\mathrm{D}$. These findings emphasize the need to focus the monitoring of vitamin D status in these specific vulnerable subgroups of Algerian postmenopausal women. Further studies are needed to confirm our findings in a larger representative population of postmenopausal women from different areas of Algeria before to address the best policies to overcome hypovitaminosis $\mathrm{D}$ in these at-risk women. However, given the growing burden of obesity in the Algerian population [51], an increase intake of vitamin D-containing foods should be encouraged, and vitamin D supplementation should be proposed more systematically. Calcium supplementation should also be proposed concomitantly given the dramatically low calcium dietary intake observed in most of the postmenopausal women studied and the well-known importance of vitamin D and calcium status adequacy for bone health at menopause [4].

\section{Conflicts of Interest}

C. Haouichat, N. Hammoumraoui, and H. Djoudi declared no conflicts of interest. N. Hammoumraoui passed away unexpectedly before the finalization of the manuscript. S. Oussedik-Lehtihet received research materials from Laboratoire Innotech International and participated as a lecturer to a symposium sponsored by this firm in Algeria. S. Lancrenon performed the statistical analysis which was funded by Laboratoire Innotech International. E. Ducros and C. Gouhier-Kodas are employed by Laboratoire Innotech International, respectively, as medical advisor and medical writer. H. Djoudi is the president of the Algerian Society of Rheumatology.

\section{References}

[1] D. A. Wahl, C. Cooper, P. R. Ebeling et al., "A global representation of vitamin D status in healthy populations," Archives of Osteoporosis, vol. 7, no. 1-2, pp. 155-172, 2012.

[2] P. Lips, "Which circulating level of 25-hydroxyvitamin D is appropriate?," Journal of Steroid Biochemistry and Molecular Biology, vol. 89-90, no. 1-5, pp. 611-614, 2004.

[3] P. Lips and N. M. van Schoor, "The effect of vitamin D on bone and osteoporosis," Best Practice \& Research Clinical Endocrinology \& Metabolism, vol. 25, no. 4, pp. 585-591, 2011. 
[4] Institute of Medicine (IOM) Committee to Review. Dietary Reference Intakes for Vitamin D and Calcium, A. C. Ross, C. L. Taylor, A. L. Yaktine, and H. B. Del Valle, Dietary Reference Intakes for Calcium and Vitamin D, National Academies Press, Washington, DC, USA, 2011.

[5] M. F. Holick, N. C. Binkley, H. A. Bischoff-Ferrari et al., "Evaluation, treatment, and prevention of vitamin D deficiency: an Endocrine Society clinical practice guideline," Journal of Clinical Endocrinology \& Metabolism, vol. 96, no. 7, pp. 1911-1930, 2011.

[6] R. Rizzoli, S. Boonen, M. L. Brandi et al., "Vitamin D supplementation in elderly or postmenopausal women: a 2013 update of the 2008 recommendations from the European Society for Clinical and Economic Aspects of Osteoporosis and Osteoarthritis (ESCEO)," Current Medical Research and Opinion, vol. 29, no. 4, pp. 305-313, 2013.

[7] S. Gaugris, R. P. Heaney, S. Boonen, H. Kurth, J. D. Bentkover, and S. S. Sen, "Vitamin D inadequacy among post-menopausal women: a systematic review," QJM: An International Journal of Medicine, vol. 98, no. 9, pp. 667-676, 2005.

[8] G. González, "Vitamin D status among healthy postmenopausal women in South America," Dermato-Endocrinology, vol. 5, no. 1, pp. 117-120, 2013.

[9] O. Bruyère, O. Malaise, A. Neuprez, J. Collette, and J.-Y. Reginster, "Prevalence of vitamin D inadequacy in European postmenopausal women," Current Medical Research and Opinion, vol. 23, no. 8, pp. 1939-1944, 2007.

[10] V. R. Tandon, S. Sharma, S. Mahajan et al., "Prevalence of vitamin D deficiency among Indian menopausal women and its correlation with diabetes: a first Indian cross sectional data," Journal of Mid Life Health, vol. 5, no. 3, pp. 121-125, 2014.

[11] S. Li, Y. Ou, H. Zhang et al., "Vitamin D status and its relationship with body composition, bone mineral density and fracture risk in urban central south Chinese postmenopausal women," Annals of Nutrition and Metabolism, vol. 64, no. 1, pp. 13-19, 2014.

[12] R. T. Chlebowski, K. C. Johnson, D. Lane et al., "25hydroxyvitamin D concentration, vitamin D intake and joint symptoms in postmenopausal women," Maturitas, vol. 68, no. 1, pp. 73-78, 2011.

[13] R. Sayed-Hassan, N. Abazid, and Z. Alourfi, "Relationship between 25-hydroxyvitamin D concentrations, serum calcium, and parathyroid hormone in apparently healthy Syrian people," Archives of Osteoporosis, vol. 9, p. 176, 2014.

[14] M. Hoteit, L. Al-Shaar, C. Yazbeck, M. Bou Sleiman, T. Ghalayini, and G. E.-H. Fuleihan, "Hypovitaminosis D in a sunny country: time trends, predictors, and implications for practice guidelines," Metabolism, vol. 63, no. 7, pp. 968-978, 2014.

[15] A. El Maataoui, A. Biaz, S. El Machtani et al., "Vitamin D status in healthy Moroccan men and women aged 50 years and older: a cross-sectional study," Archives of Osteoporosis, vol. 11, no. 1, p. 24, 2016.

[16] G. Smith, S. J. Wimalawansa, A. Laillou et al., "High prevalence of vitamin $\mathrm{D}$ deficiency in Cambodian women: a common deficiency in a sunny country," Nutrients, vol. 8, no. 5, p. E290, 2016.

[17] A. N. Hussain, A. H. Alkhenizan, M. El Shaker, H. Raef, and A. Gabr, "Increasing trends and significance of hypovitaminosis D: a population-based study in the Kingdom of Saudi Arabia," Archives of Osteoporosis, vol. 9, p. 190, 2014.

[18] M. Djennane, S. Lebbah, C. Roux, H. Djoudi, E. Cavalier, and J. C. Souberbielle, "Vitamin D status of schoolchildren in Northern Algeria, seasonal variations and determinants of vitamin D deficiency," Osteoporosis International, vol. 25, no. 5, pp. 1493-1502, 2014.
[19] M. E. Arlot, E. Sornay-Rendu, P. Garnero, B. Vey-Marty, and P. D. Delmas, "Apparent pre- and postmenopausal bone loss evaluated by DXA at different skeletal sites in women: the OFELY cohort," Journal of Bone and Mineral Research, vol. 12, no. 4, pp. 683-690, 1997.

[20] A. Bouzid and D. Meskine, "Osteoporosis in a cohort of 1062 postmenopausal women," in Proceedings of 18th European Congress of Endocrinology, Endocrine Abstracts, vol. 41, p. EP125, Munich, Germany, May 2016.

[21] WHO Scientific Group, "Prevention and management of osteoporosis," in Tech. Rep. 921, World Health Organization, Geneva, Switzerland, 2003.

[22] NIH Office of Dietary Supplements, "Vitamin D dietary supplement fact sheet," February 2016, https://ods.od.nih. gov/factsheets/VitaminD-HealthProfessional/.

[23] F. E. Abourazzak, H. Khazzani, S. Mansouri et al., "Recommendations of the Moroccan Society of Rheumatology on vitamin D in adults," Revue Marocaine de Rhumatologie, vol. 35, pp. 3-15, 2016.

[24] P. Fardellone, J. L. Sebert, M. Bouraya et al., "Evaluation of the calcium content of diet by frequential self-questionnaire," Revue du Rhumatisme et des Maladies Ostéo-Articulaires, vol. 58, no. 2, pp. 99-103, 1991.

[25] F. Allali, S. El Aichaoui, H. Khazani et al., "High prevalence of hypovitaminosis D in Morocco: relationship to lifestyle, physical performance, bone markers, and bone mineral density," Seminars in Arthritis and Rheumatism, vol. 38, no. 6, pp. 444-451, 2009.

[26] A. El Maghraoui, Z. Ouzzif, A. Mounach et al., "Нypovitaminosis $\mathrm{D}$ and prevalent asymptomatic vertebral fractures in Moroccan postmenopausal women," BMC Womens Health, vol. 12, p. 11, 2012.

[27] N. Meddeb, H. Sahli, M. Chahed et al., "Vitamin D deficiency in Tunisia," Osteoporosis International, vol. 16, no. 2, pp. 180-183, 2005.

[28] M. Katrinaki, M. Kampa, A. Margioris, E. Castanas, and N. Malliaraki, "Vitamin D levels in a large Mediterranean cohort: reconsidering normal cut-off values," Hormones, vol. 15, no. 2, pp. 205-223, 2016.

[29] P. Lips, A. Wiersinga, F. C. van Ginkel et al., "The effect of vitamin D supplementation on vitamin D status and parathyroid function in elderly subjects," Journal of Clinical Endocrinology \& Metabolism, vol. 67, no. 4, pp. 644-650, 1988.

[30] F. M. Gloth, C. M. Gundberg, B. W. Hollis, J. G. Haddad, and J. D. Tobin, "Vitamin D deficiency in homebound elderly persons," Journal of the American Medical Association, vol. 274, no. 21, pp. 1683-1686, 1995.

[31] O. Hochwald, I. Harman-Boehm, and H. Castel, "Hypovitaminosis D among inpatients in a sunny country," Israel Medical Association Journal, vol. 6, no. 2, pp. 82-87, 2004.

[32] A. Rassouli, I. Milanian, and M. Moslemi-Zadeh, "Determination of serum 25-hydroxyvitamin $\mathrm{D}(3)$ levels in early postmenopausal Iranian women: relationship with bone mineral density," Bone, vol. 29, no. 5, pp. 428-430, 2001.

[33] P. Lips, T. Duong, A. Oleksik et al., "A global study of vitamin D status and parathyroid function in postmenopausal women with osteoporosis: baseline data from the multiple outcomes of raloxifene evaluation clinical trial," Journal of Clinical Endocrinology \& Metabolism, vol. 86, no. 3, pp. 1212-1221, 2001.

[34] P. Garnero, F. Munoz, E. Sornay-Rendu, and P. D. Delmas, "Associations of vitamin D status with bone mineral density, bone turnover, bone loss and fracture risk in healthy postmenopausal women. The OFELY study," Bone, vol. 40, no. 3, pp. 716-722, 2007. 
[35] H. A. Bischoff-Ferrari, "Optimal serum 25-hydroxyvitamin D levels for multiple health outcomes," Advances in Experimental Medicine and Biology, vol. 810, pp. 500-525, 2014.

[36] M. H. Gannagé-Yared, G. Maalouf, S. Khalife et al., "Prevalence and predictors of vitamin D inadequacy amongst Lebanese osteoporotic women," British Journal of Nutrition, vol. 101, no. 4, pp. 487-491, 2009.

[37] E. K. Nichols, I. M. Khatib, N. J. Aburto et al., "Vitamin D status and determinants of deficiency among non-pregnant Jordanian women of reproductive age," European Journal of Clinical Nutrition, vol. 66, no. 6, pp. 751-756, 2012.

[38] M. Pereira-Santos, P. R. Costa, A. M. Assis, C. A. Santos, and D. B. Santos, "Obesity and vitamin D deficiency: a systematic review and meta-analysis," Obesity Reviews, vol. 16, no. 4, pp. 341-349, 2015.

[39] L. K. Pourshahidi, "Vitamin D and obesity: current perspectives and future directions," Proceedings of the Nutrition Society, vol. 74, no. 2, pp. 115-124, 2015.

[40] Y. Yao, L. Zhu, L. He et al., "A meta-analysis of the relationship between vitamin D deficiency and obesity," International Journal of Clinical and Experimental Medicine, vol. 8, no. 9, pp. 14977-14984, 2015.

[41] S. Vanlint, "Vitamin D and obesity," Nutrients, vol. 5, no. 3, pp. 949-956, 2013.

[42] J. Wortsman, L. Y. Matsuoka, T. C. Chen, Z. Lu, and M. F. Holick, "Decreased bioavailability of vitamin D in obesity," American Journal of Clinical Nutrition, vol. 72, no. 3, pp. 690-693, 2000.

[43] A. T. Drincic, L. A. Armas, E. E. Van Diest, and R. P. Heaney, "Volumetric dilution, rather than sequestration best explains the low vitamin D status of obesity," Obesity, vol. 20, no. 7, pp. 1444-1448, 2012.

[44] P. Lee, J. R. Greenfield, M. J. Seibel, J. A. Eisman, and J. R. Center, "Adequacy of vitamin D replacement in severe deficiency is dependent on body mass index," American Journal of Medicine, vol. 122, no. 11, pp. 1056-1060, 2009.

[45] J. C. Gallagher, V. Yalamanchili, and L. M. Smith, "The effect of vitamin D supplementation on serum 25(OH)D in thin and obese women," Journal of Steroid Biochemistry and Molecular Biology, vol. 136, pp. 195-200, 2013.

[46] C. P. Earthman, L. M. Beckman, K. Masodkar, and S. D. Sibley, "The link between obesity and low circulating 25hydroxyvitamin D concentrations: considerations and implications," International Journal of Obesity, vol. 36, no. 3, pp. 387-396, 2012.

[47] Y. J. Foss, "Vitamin D deficiency is the cause of common obesity," Medical Hypotheses, vol. 72, no. 3, pp. 314-321, 2009.

[48] I. González-Molero, G. Rojo-Martínez, S. Morcillo et al., "Hypovitaminosis D and incidence of obesity: a prospective study," European Journal of Clinical Nutrition, vol. 67, no. 6, pp. 680-682, 2013.

[49] K. S. Vimaleswaran, D. J. Berry, C. Lu et al., "Causal relationship between obesity and vitamin D status: bidirectional Mendelian randomization analysis of multiple cohorts," PLoS Medicine, vol. 10, no. 2, p. e1001383, 2013.

[50] J. C. Souberbielle, J. J. Body, J. M. Lappe et al., "Vitamin D and musculoskeletal health, cardiovascular disease, autoimmunity and cancer: recommendations for clinical practice," Autoimmunity Reviews, vol. 9, no. 11, pp. 709-715, 2010.

[51] M. Atek, P. Traissac, J. El Ati et al., "Obesity and association with area of residence, gender and socio-economic factors in Algerian and Tunisian adults," PLoS ONE, vol. 8, no. 10, p. e75640, 2013. 


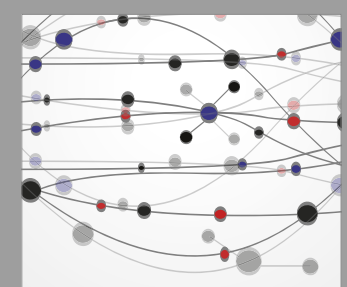

The Scientific World Journal
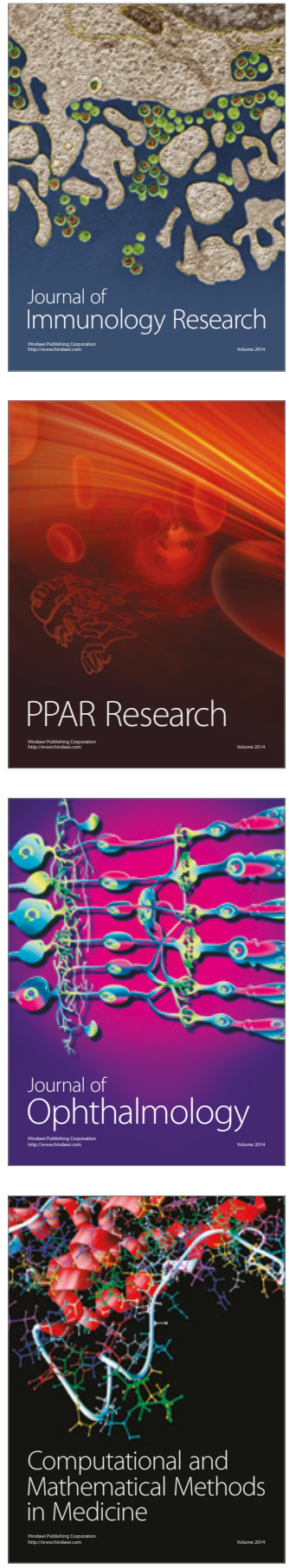

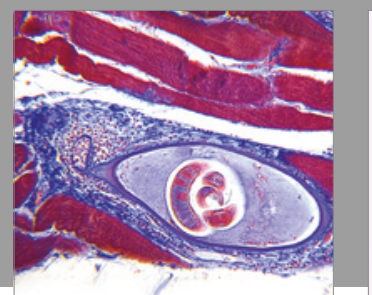

Gastroenterology Research and Practice
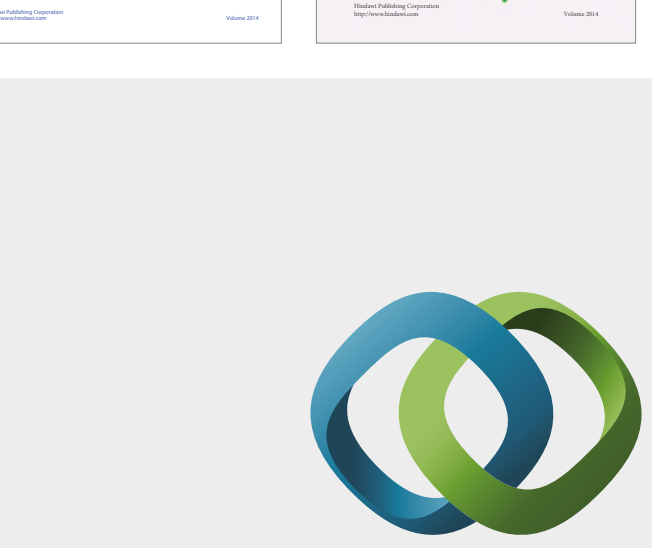

\section{Hindawi}

Submit your manuscripts at

https://www.hindawi.com
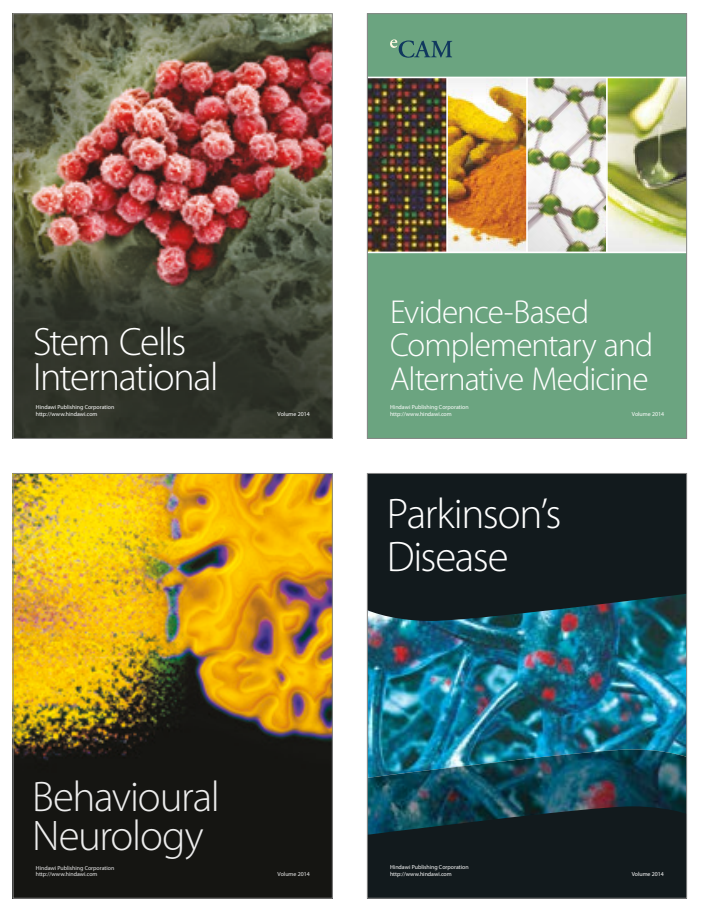
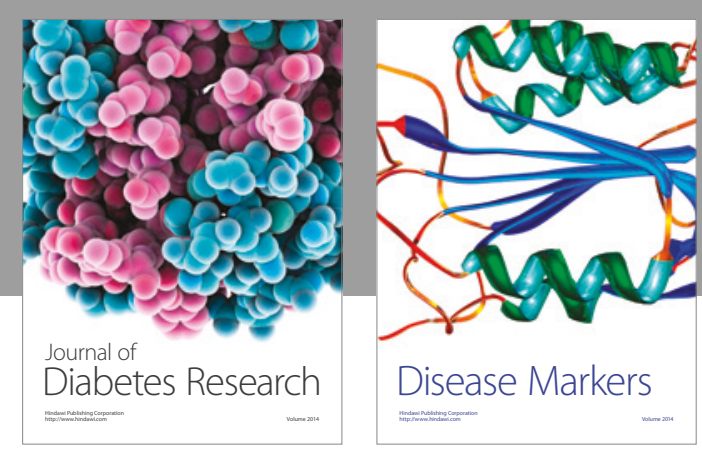

Disease Markers
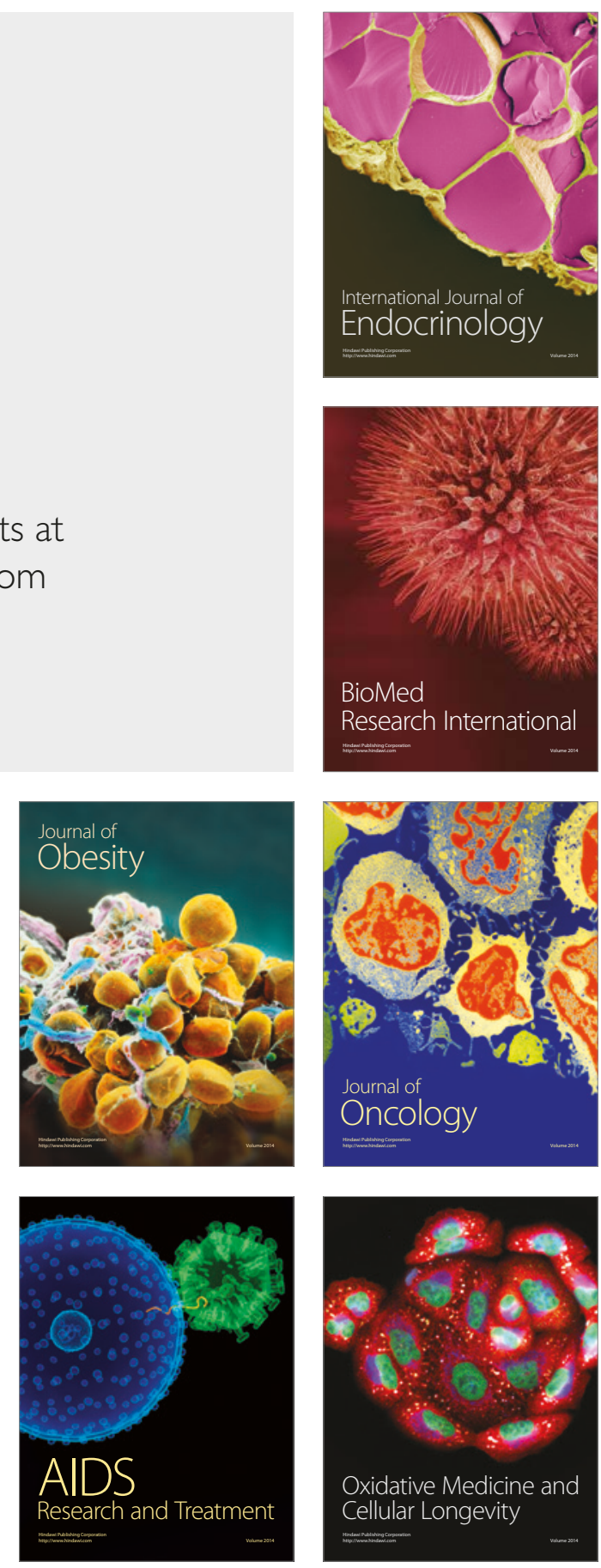